\title{
Mito y agonismo: un contrapunto filosófico en el marxismo abierto de José Carlos Mariátegui
}

\author{
Myth and agonism: a philosophical counterpoint in the open marxism of \\ José Carlos Mariátegui
}

\section{Joel Rojas Huaynates}

Facultad Latinoamericana de Ciencias Sociales - FLACSO, Quito, Ecuador Contacto: jwrojasfl@flacso.edu.ec htpps://orcid.org/0000-0003-2513-8287

\section{Resumen}

Este artículo tiene como objetivo analizar los conceptos de mito y agonismo en la obra de José Carlos Mariátegui, quien es considerado como el primer marxista latinoamericano. En primer lugar, describiremos la experiencia italiana del pensador peruano, la cual le permitió conocer la obra de Antonio Labriola y Benedetto Croce, así como la participación en el debate marxista italiano de Georges Sorel. Este primer punto permitirá delimitar la obra de Mariátegui como marxismo abierto frente al dogmatismo del marxismo ortodoxo. En segundo lugar, a manera de contrapunto, desarrollaremos el concepto de mito y agonismo de Mariátegui para demostrar su actualidad en el debate de la filosofía política contemporánea.

Palabras clave: Marxismo abierto; Mito; Agonismo; José Carlos Mariátegui; Ontología.

\begin{abstract}
This article aims to analyze the concepts of myth and agonism in the work of José Carlos Mariátegui, who is considered the first Latin American Marxist. In the first place, we will describe the Italian experience of the Peruvian thinker that allowed him to know the work of Antonio Labriola and Benedetto Croce, and the participation in the Italian Marxist debate of Georges Sorel. This first point will make it possible to delimit Mariátegui's work as open marxism in the face of the dogmatism of orthodox Marxism. Second, as a counterpoint, we will develop the concept of myth and agonism Mariátegui's to demonstrate its relevance in the debate of contemporary political philosophy.
\end{abstract}

Keywords: Open marxism; Myth; Agonism; José Carlos Mariátegui; Ontology. 


\section{La experiencia italiana y el debate del materialismo histórico}

La experiencia italiana ${ }^{1}$ de José Carlos Mariátegui $^{2}$ consolidó su formación teórica y política porque tuvo acceso de manera directa a la obra de Antonio Labriola y Benedetto Croce. La publicación de la correspondencia, editada por el italiano Antonio Melis, permitió enterarnos de que Mariátegui tuvo conocimiento de L'Ordine Nuovo, revista dirigida por Antonio Gramsci. Y la investigación de Fernanda Beigel sostiene que: “[d]os son los principales pilares del aprendizaje italiano que contribuyeron en la recepción del marxismo en Mariátegui y dejaron rastros luego en su acción peruana: el ordinovismo turinés y el editorialismo gobettiano" (2005, p. 28). Dicha conclusión de Beigel es meramente parcial, pues Labriola y Croce tuvieron, además, una asimilación teórica en el pensador peruano. Este punto es defendido por Robert Paris (1973), quien considera hallar un "crocianismo latente". En los siguientes párrafos, a manera de complemento sobre la experiencia italiana ${ }^{3}$, desarrollaré la influencia filosófica itálica en la que se formó Mariátegui y tendré como hilo conductor a Labriola y Croce para concluir con la participación de Sorel. Este filósofo francés se inserta en la trama teórica mariateguiana no propiamente desde la tradición francesa, sino desde la italiana, como veremos enseguida.

La recepción de la obra de Marx en Italia, antes del surgimiento de la Segunda Internacional (1889), fue casi nula; uno de los factores se debió a que las obras del filósofo alemán no tuvieron allí circulación editorial, a diferencia de otros países europeos. No obstante, el marxismo pudo consolidarse como movimiento político por medio del Partido Socialista Italiano; este lo integraban abogados, profesores, médicos e incluso comerciantes, “[...] quienes se atribuían el derecho de interpretar el marxismo de una u otra forma de acuerdo con la postura política asumida respecto de algún evento de actualidad sin miedo a incurrir en grotescas contradicciones" (Kohn, 1986, p. 21). Frente a esta situación, en la cual no se tuvo una doctrina definida, aparecieron los escritos de Antonio Labriola con la finalidad de llenar ese vacío a partir de una lectura directa de Marx ${ }^{4}$. En su escrito En memoria del manifiesto comunista, este filósofo italiano se distanció de la 
lectura positivista del materialismo histórico, indicando que: “[...] aceptamos de buen grado el predicado de científicos, siempre y cuando que con ello no se nos equipare a los positivistas, gentes poco gratas las más de las veces, que hacen de la 'ciencia' un monopolio" (Labriola, 1961, p. 305). Esta postura de Labriola solo era compartida por un sector minoritario de teóricos del materialismo histórico, quienes criticaban el aspecto abstracto de los positivistas, cuyo objetivo fue

[...] dar expresión teórica e interpretación práctica a esos factores concretos que nos brinda el análisis histórico [...] de ese proceso que entrañan las relaciones reales de la vida social que tienen en nosotros su sujeto y su objeto, su causa y su fin. (Labriola, 1961, p. 395)

Por tanto, la intención de Labriola fue cuestionar los postulados metafísicos de los positivistas, como el concepto de evolución que introducían al materialismo histórico marxista y, más bien, demuestra que el comunismo crítico se basa en la experiencia de un contexto particular, más allá de posturas utópicas sobre la sociedad:

En la doctrina del comunismo crítico, la sociedad toda descubre, en un momento de su desarrollo general, la causa de su marcha funesta, y en uno de sus recodos salientes del camino cobra conciencia de sí propia y comprende y proclama las leyes de su dinámica. Los pronósticos del Manifiesto no tienen nada que ver con ninguna fecha; no eran ninguna predicción ni ninguna profecía, sino simplemente se anticipaban a exponer la transformación orgánica de la sociedad. (Labriola, 1961, p. 324)

Como deducimos de la cita, Labriola agrega la dimensión de la crítica al comunismo en contra de las posturas positivistas que se regían por leyes científicas. Sin embargo, este autor, a su manera, sigue afirmando una premisa del núcleo duro del marxismo, a saber: la estructura económica es determinante de lo social. En Del materialismo histórico. Dilucidación preliminar (1945), Labriola cuestionó las pretensiones de las posturas éticas sostenidas por algunos socialistas, ya que la ética parte de las premisas apriorísticas que rigen el desarrollo de lo social. A diferencia de la lectura ortodoxa sobre la rigidez entre estructura y superestructura, el filósofo italiano no rechazó la ética como producto sin más de la economía, sino la refutó por la pretensión de su reduccionismo de 
lo social, considerándola un elemento de la superestructura ${ }^{5}$. Más que postular reducciones, a Labriola le interesó conocer las particularidades y condiciones de la configuración de lo social para comprender el hecho histórico concreto. Frente a este punto menciona lo siguiente:

Recomendar la moral a los hombres suponiendo o ignorando sus condiciones, fue hasta el presente la mira y el género de argumentación de todos los catequistas. Reconocer que estas condiciones son dadas por el circunstanciado ambiente social, he aquí los que los comunistas oponen a la utopía y a la hipocresía de los predicadores de la moral.

(Labriola, 1945, p. 175)

Por otro lado, Labriola si bien critica toda pretensión metafísica en torno al concepto de evolución, sin embargo, no tiene la misma postura frente al concepto de progreso: “[...] si la ideología burguesa, reflejo de la tendencia a la unificación capitalista, ha proclamado el progreso del género humano, el materialismo histórico ha descubierto que en la antítesis estuvo hasta ahora la causa de todo suceso histórico" (Labriola, 1945, p. 205). El progreso, según este pensador, es comprendido como proceso histórico que mediante conflictos y luchas representa la antítesis frente a la perspectiva del capitalismo burgués. A partir de dichos primeros escritos, Labriola ya era reconocido como un teórico del marxismo. En Francia, Sorel fundó en 1895 la revista Le Devenir Social que tuvo como propósito promover y difundir el debate sobre el marxismo; para eso contaba con el apoyo de Labriola y su discípulo Croce (Marini, 2012, p. 68). Por si fuera poco, Sorel escribió el prefacio del libro en francés Ensayos sobre la concepción materialista de la historia, que consta de los trabajos Memoria del Manifiesto comunista y Del materialismo histórico. Dilucidación preliminar. El distanciamiento de ambos se realiza porque Sorel propuso un revisionismo de las premisas del marxismo ortodoxo, a diferencia de Labriola que las asumía y consideró al materialismo histórico como "[...] concepto general de la vida y del mundo, de la crítica de la economía y de interpretación de la política del proletariado" (Marini, 2012, p. 69). Ya en Alemania, a través Eduard Bernstein, se propuso hacer una serie de revisiones de carácter reformista y electoral en el SPD (Partido Socialdemocrático Alemán, por sus siglas en el idioma original). Este 
suceso repercutió en Sorel $(2005,2014)$, que ya tenía diferencias con el marxismo ortodoxo, y realizó unos artículos describiendo esa coyuntura como "la crisis del marxismo". Como resultado, en Filosofia y socialismo Labriola respondió a esta supuesta "crisis del marxismo" y asumió tres presupuestos fundamentales sobre el materialismo histórico:

El primero responde a la necesidad práctica, propia a los partidos socialistas, de adquirir un conocimiento completo de las condiciones específicas del proletariado en cada país y de hacer depender de las causas, de las promesas y de los peligros de la situación política, la acción del socialismo. El segundo puede influir, e influirá ciertamente, para modificar las corrientes de historiografía en tanto que permita que este arte vaya al terreno de las luchas de clases y a la combinación social que resulte de éstas, dada la correspondiente estructura económica que cada historiador debe en adelante conocer y comprender. El tercero se relaciona con la investigación de los principios rectores, cuya inteligencia y desenvolvimiento necesitan de esa orientación general. (Labriola, s/f, p. 63)

Este apretado análisis sobre Labriola permitirá comprender con más detalle la participación, en este debate marxista, de Croce ${ }^{7}$, quien tuvo una relación no solo teórica sino amical con Mariátegui ${ }^{8}$. Este filósofo italiano, en el prólogo de Materialismo histórico y economía marxista (1942), aclara que no fue un marxista y no hubo una conversión frente al marxismo, como sostienen algunos críticos ortodoxos. Su propuesta busca "[...] liberar el núcleo sano y realista del pensamiento de Marx, de los adornos metafísicos y literarios de su autor y de las exégesis y deducciones poco cautas de la escuela" (Croce, 1942, p. 10). El materialismo histórico — según Croce - no es una filosofía de la historia, sino un método de interpretación ${ }^{9}$. Este cuestionamiento de Croce al materialismo histórico se opone, a manera de superación, contra la teología y la metafísica: “[...] la vieja filosofía de la historia recibió un golpe mortal. Así nació, con un sentido casi de menosprecio y hostilidad la frase: 'hacer filosofía de la historia', para significar: hacer historia fantástica y artificiosa, y acaso también tendenciosa" (Croce, 1942, p. 21). La pretensión de Croce es superar el esquema teleológico, porque el marxismo no anticipaba ni predeterminaba el curso de los hechos. 
De manera que Croce utiliza el concepto de desenvolvimiento para englobar de manera abierta los hechos históricos, a diferencia de los positivistas:

El mal está en que el concepto de evolución en manos de los positivistas, a menudo mediante un traspaso demasiado fácil de la vacuidad formal que, sin embargo, es su verdad, para llenarse con un contenido muy semejante a los contenidos teleológicos y metafísicos. Y baste como muestra, la casi religiosa unción y veneración con que se oye hablar a los elementos democráticos del sagrado misterio de la Evolución. (Croce, 1942, p. 22)

De este modo, Croce rechazó que el materialismo histórico sea considerado como ley científica, tal cual lo sostuvieron marxistas ortodoxos como Gueorgui Plejánov y Karl Kautsky. Y Croce, retomando la crítica de Marx a Hegel, sostiene que: "[1] historia no es un proceso de la Idea, o sea de una realidad racional trascendente, sino un sistema de fuerzas: a la concepción trascendente se opondría la concepción inmanente" (Croce, 1942, p. 24). Esta sustitución de la Idea como sistema de fuerzas permite cuestionar las posturas teleológicas donde el concepto de progreso rige el curso de la humanidad como instancia trascendente - Walter Benjamin ${ }^{10}$ continuaría a su manera este debate dentro del marxismo- - Por tal motivo, el materialismo histórico no es la última y definitiva filosofía, sino que está en constante reformulación teórica, pues es un método que interpreta un contexto particular. Croce no solo cuestionó el positivismo, sino también a los marxistas que reducían la historia al factor económico. Ello debido a que el proceso histórico se desarrolla por una complejidad de fuerzas, por eso rechaza el materialismo histórico como teoría cerrada:

El materialismo histórico surgió de la necesidad de percatarse de una determinada configuración social, no ya de un propósito de búsqueda de los factores de la vida histórica; y se constituyó en la cabeza de políticos y de revolucionarios, y no en la de fríos y pacientes sabios de biblioteca. (Croce, 1942, p. 33)

Por otro lado, Croce hace hincapié en lo contingente de los hechos históricos, pues estas determinaciones históricas entrelazan el materialismo histórico y el socialismo, despojándolos de residuos teleológicos. Croce toma como ejemplo la historia de la verdad en la ciencia que, a partir del materialismo 
histórico, tiende a visibilizar las condiciones de los descubrimientos científicos. Sin embargo, Croce no pretende caer en un relativismo ni en un escepticismo, pues no se relativizan las verdades en las investigaciones históricas, sino se trata de explicitar las condiciones que determinaron estas verdades. No se trata de invalidar la teoría económica de Marx, sino presentarla como inacabada debido a la peculiaridad del contexto histórico estudiado — como vimos antes, Labriola lo propuso como una premisa fundamental de su materialismo histórico- - En suma, Croce formula cuatro observaciones al marxismo para continuar con su planteamiento como método: a) la economía marxista no es una ciencia económica general, sino una economía sociológica comparativa; b) el materialismo histórico debe rechazar conceptos apriorísticos porque es un método de interpretación histórica; c) la imposibilidad deductiva del programa social marxista a partir de proposiciones científicas abstractas o de la ciencia pura; y d) el rechazo de una amoralidad o una antieticidad dentro del marxismo (Croce, 1942, pp. 138-140).

En resumidas cuentas, estas son las posturas teóricas de Labriola y Croce en torno al marxismo. Cuando Mariátegui llegó a Italia, dichas posiciones teóricas ya estaban definidas: Labriola era considerado como parte de la tradición marxista italiana, a diferencia de Croce que se distanció de estas polémicas marxistas y buscó nuevas rutas en su reflexión filosófica. Posteriormente, Gramsci, con una propia postura, retomó este suceso por las implicancias teóricas en el contexto posterior a la Revolución rusa y dedicó un estudio crítico pormenorizado a Croce ${ }^{11}$. De igual forma, Mariátegui después de su experiencia italiana no tuvo una postura pasiva o acrítica, sino que se apropió propositivamente de los recursos teóricos de este debate. Esta experiencia italiana le permitió tener una propia lectura del pensador alemán, pero de ello no se infiere que la filosofía italiana haya sido un filtro para su lectura de Marx, como sostienen José Aricó ${ }^{12}$ y Diego Meseguer (1974). El investigador norteamericano Harry Vanden (1975) ha demostrado que Mariátegui tuvo en su biblioteca la traducción italiana y francesa de El Capital y las obras completas en francés de Lenin. Por consiguiente, sostengo que la experiencia italiana es un momento en la trama teórica de Mariátegui y, en efecto, la filosofía italiana no es una influencia predominante en su corpus teórico. Recordemos que 
Mariátegui confesó sin más ser un marxista convicto y confeso. Por eso, sostengo que su obra es representada como un marxismo abierto, esta noción fue acuñada por Augusto Salazar Bondy en su estudio de la obra mariateguiana donde señala la libertad del crítico y polemista frente a los dogmas catequistas del materialismo simplista. A lo largo de esta investigación utilizaremos dicho concepto ${ }^{13}$ como hilo conductor, pero esto no quiere decir que Mariátegui se distancie de las premisas del núcleo duro del marxismo: a) el análisis económico es el factor determinante de la historia, b) lo económico determina una superestructura de la sociedad y c) la lucha de clases es el motor de la historia (Sobrevilla, 2012, pp. 394-395).

En los siguientes subcapítulos desarrollaremos este marxismo abierto a través de los conceptos de mito y agonismo.

\section{El mito como núcleo de la praxis social}

Este análisis parte del artículo de Mariátegui "El hombre y el mito", publicado en Mundial el 16 de enero de 1925. El autor plantea la necesidad de un mito que sea sinónimo de fe y de esperanza, frente a la razón y la ciencia que anulan la necesidad de infinito, pues "[e]l hombre, antes sobrecogido ante lo sobrenatural, se ha descubierto de pronto un desorbitante poder para corregir y rectificar la Naturaleza. Esta sensación ha desalojado de su alma las raíces de la vieja metafísica" (Mariátegui, 1972, p. 24). Así, Mariátegui introduce el concepto de mito no como mera metafísica, sino a partir del hombre concreto que necesita el mito como irrupción en un sentido histórico. El mito permite entonces una superación de la metafísica entendida como abstracción, si bien Mariátegui acepta la necesidad de infinito en el hombre, pero también el mito como superación en tanto núcleo central de la praxis social. El proletariado, a diferencia de la burguesía, posee el mito de la revolución social. La estrategia argumental de Mariátegui parte de una postura ontológica del hombre hacia un análisis social donde el mito sería la imbricación para constituir finalmente una praxis social:

La fuerza de los revolucionarios no está en su ciencia; está en su fe, en su pasión, en su voluntad. Es una fuerza religiosa, mística, espiritual. Es la fuerza del Mito. La emoción revolucionaria, como escribí en un artículo sobre Gandhi, es una emoción religiosa. Los motivos 
religiosos se han desplazado del cielo a la tierra. No son divinos; son humanos, son sociales. (Mariátegui, 1972, p. 27)

El recurso del concepto de mito permite a Mariátegui confrontar la decadencia de la burguesía y oponerse al racionalismo y al cientificismo. Más adelante Mariátegui, en Defensa del marxismo (1981), retoma el concepto de mito de Georges Sorel para criticar las posturas liquidacionistas del marxismo. El pensador peruano distingue entre un revisionismo positivo (o fecundo) realizado por Sorel y un revisionismo negativo (o estéril) representado por Henri de Man. Este tipo de revisionismo positivo lo entenderemos como marxismo abierto. De tal modo, la obra de Sorel, a los ojos de Mariátegui, representa un conspicuo desarrollo del marxismo:

\begin{abstract}
A través de Sorel, el marxismo asimila los elementos y adquisiciones sustanciales de las corrientes filosóficas posteriores a Marx. Superando las bases racionalistas y positivistas del socialismo de su época, Sorel encuentra en Bergson y los pragmatistas ideas que vigorizan el pensamiento socialista, restituyéndolo a la misión revolucionaria de la cual lo había gradualmente alejado el aburguesamiento intelectual y espiritual de los partidos y de sus parlamentarios, que se satisfacían, en el campo filosófico, con el historicismo más chato y el evolucionismo más pávido. (1981, p. 21)
\end{abstract}

Si bien la obra de Sorel se inserta en la trama teórica de Mariátegui, sin embargo no es una principal influencia, como pretende persuadirnos Hugo García Salvatecci (1979). Este, en su libro Sorel y Mariátegui sostiene que el pensador peruano no es un marxista, sino un soreliano porque representa su principal fuente teórica. El argumento principal de García Salvatecci es que Mariátegui ubicó en el sindicalismo la fuerza revolucionaria de un nuevo orden. Si bien Mariátegui apoyó y organizó la creación de sindicatos, su principal objetivo fue la fundación de un partido político. De tal modo, Mariátegui se opuso indirectamente a la crítica de Sorel sobre los partidos políticos. Ello lo veremos a continuación.

Esta lectura de Sorel realizada por Mariátegui parte de su experiencia europea a través de Benedetto Croce, quien promovió la publicación de la obra soreliana en la academia italiana, y Arturo Labriola ${ }^{14}$, quien lo introdujo en el 
ámbito socialista llegando hasta los jóvenes marxistas, como lo fue Gramsci. Centrémonos en este último para ver cómo realizó una síntesis entre el príncipe de Maquiavelo y el mito de Sorel. El príncipe maquiaveliano, según Gramsci, es la figura abstracta del jefe que conducirá al pueblo en la constitución de un Estado, a diferencia del mito soreliano que tuvo limitaciones en la compresión sobre los partidos políticos debido a su acción espontánea por medio de la huelga general. Esta huelga, para Gramsci, representa una actividad pasiva de carácter negativo porque solo es una instancia preliminar; así, frente a ello, contrapone un carácter positivo a través de la formación de la voluntad colectiva, a diferencia de Sorel que apuesta por ese "impulso de lo irracional, de lo 'arbitrario' (en el sentido bergsoniano de 'impulso vital')" (Gramsci, 1980, p. 14), que solo representa una mera espontaneidad. El cuestionamiento de Gramsci radica en que el mito soreliano, si bien posibilita una voluntad colectiva, cuando esta voluntad pase a la fase positiva ocurrirá una dispersión de voluntades singulares. Por eso, Gramsci apela a la conformación del partido político de la clase obrera:

El príncipe moderno, el mito-príncipe, no puede ser una persona real, un individuo concreto; sólo puede ser un organismo, un elemento de sociedad complejo en el cual comience a concretarse una voluntad colectiva reconocida y afirmada parcialmente en la acción. Este organismo ya ha sido dado por el desarrollo histórico y es el partido político: la primera célula en la que se resumen los gérmenes de voluntad colectiva que tienden a devenir universales y totales. (Gramsci, 1980, p. 15)

Además, Gramsci cuestiona el carácter abstracto del mito que provocó la aversión de Sorel hacia los jacobinos; por el contrario, estos representan la figura del príncipe moderno, ya que concretizaron la voluntad colectiva. Este postulado de Gramsci parte del contexto italiano atrasado, que tuvo una economíacorporativa y no generó las condiciones para constituir un Estado moderno. En cambio, en la Francia de Sorel existían los sindicatos como una fuerza importante de movilización social por medio de la huelga general proletaria. En conclusión, el mito soreliano es insuficiente como formación de una voluntad colectiva en el caso italiano, por eso Gramsci, ante esta insuficiencia, imbrica el príncipe maquiaveliano al mito soreliano, con el objetivo de constituir una voluntad colectiva 
de carácter nacional-popular a través del partido político. Si bien Mariátegui no desarrolla literalmente el mito en el sentido de Gramsci ${ }^{15}$, el pensador peruano fue consciente de que no solo a través del mito se posibilitaría una revolución social, sino que era inexorable la gestación de diversas organizaciones obreras y la creación del Partido Socialista Peruano.

El mito mariateguiano ha sido posteriormente analizado y desarrollado principalmente por dos autores. El primero es el sociólogo Aníbal Quijano, quien parte de una ambigüedad del marxismo mariateguiano a través de dos puntos: 1) la tensión entre una concepción del marxismo como método o como filosofía de la historia, 2) la centralidad de la voluntad individual a partir del mito. Sobre la base de estos dos ejes, Quijano plantea que "Mariátegui parece levantar el problema de la necesidad de una filosofía de la historia para completar la obra de Marx, y para ello apela a otras fuentes filosóficas" (1981, p. 66). El argumento de Quijano concluye que esta "[...] amalgama de tendencias filosóficas, todas no solamente ajenas sino opuestas al marxismo, ingresan a componer una suerte de filosofía de la historia" (1981, p. 67). Además, prosigue este autor, Mariátegui, al asumir el materialismo como base de la epistemología marxista, se aleja del debate epistemológico para dedicarse a reflexionar en el ámbito de la moral.

Este planteamiento de Quijano es incoherente porque carece de sustento. El mismo Mariátegui se opuso determinar el marxismo como una filosofía de la historia, ya que lo consideró como un método de interpretación ${ }^{16}$ del presente en sintonía con la propuesta de Croce. Recordemos las palabras de Mariátegui frente a la filosofía de la historia:

El materialismo histórico no es, precisamente, el materialismo metafísico o filosófico, ni es una Filosofía de la Historia, dejada atrás por el progreso científico. Marx no tenía por qué crear más que un método de interpretación histórica de la sociedad actual. (1981, p. 40)

En este punto coincido con Augusto Salazar Bondy, quien señala que el materialismo histórico en Mariátegui no es "[...] un sistema abstracto de interpretación del mundo, sino la interpretación actual y objetiva de una sociedad actual y objetiva" (1965, p. 315), pues el marxismo abierto mariateguiano asimila 
otras corrientes filosóficas. Además, a diferencia de lo que sostiene Quijano, sí encontramos en el marxismo de Mariátegui un debate epistemológico. La crítica al determinismo mecanicista del marxismo vulgar o, como lo llamaba Mariátegui, de los ortodoxos catequistas, se da en términos epistemológicos.

Posteriormente, Quijano retoma su planteamiento sobre Mariátegui para sostener que la "ambigüedad mariateguiana" es representada por la oposición $\operatorname{logos} /$ mito. Habíamos mencionado que la ambigüedad en el marxismo de Mariátegui se daba entre: a) el marxismo como método para el conocimiento de la realidad y b) como filosofía de la historia. Quijano (1986) sostiene que en el punto b) encontramos una orientación explícitamente religiosa y metafísica, por eso Mariátegui introdujo mediante la vía de la ambigüedad el concepto de mito soreliano. En esta trama teórica de Mariátegui, Quijano percibe el carácter del pensamiento latinoamericano, es decir, un constante movimiento de reflexión y conocimiento entre los conceptos europeos frente a un contexto determinado. La conclusión de Quijano sobre esta ambigüedad mariateguiana es la siguiente:

Este campo cultural original implica que el logos y el mito no son, no pueden ser externos entre sí, sino contradictorios en un mismo movimiento intelectivo en que la imaginación actúa con y a través del análisis lógico para constituir el conocimiento como representación global o globalizante y en movimiento que es indispensable para otorgar status supra-histórico, mítico, pues, a lo que sólo puede realizarse en la historia a través de muchas trascendencias y transfiguraciones. (1986, pp. 109-110)

Esta conclusión le permite a Quijano, a partir de la ambigüedad mariateguiana, sostener el carácter de tensión en el pensamiento latinoamericano; como ejemplo tenemos la obra de Gabriel García Márquez, José María Arguedas y Juan Rulfo. De este modo, Quijano introduce el concepto de mito a un campo epistemológico donde logos/mito no son oposiciones, sino se encuentran imbricados. Posteriormente, en Modernidad, identidad y utopía en América Latina (1988), Quijano hace un análisis histórico sobre la modernidad para indicar que frente a la crisis de la razón instrumental ${ }^{17}$ europea hallamos una racionalidad alternativa en América Latina. Y luego Quijano, en El marxismo en Mariátegui: 
una propuesta de racionalidad alternativa (1995), sostiene que esta racionalidad alternativa frente a la modernidad la ubicamos en Marx y que su desarrollo teórico lo realiza Mariátegui. Sin embargo, el análisis de la ambigüedad es refutado por la noción de marxismo abierto propuesto por Salazar Bondy. No se trata de que haya una separación maniquea entre lo que es marxista y lo que no es marxista o de una racionalidad instrumental y una racionalidad alternativa, sino que la matriz marxista es enriquecida por otras matrices como el voluntarismo, el pragmatismo, el anarcosindicalismo soreliano, entre otras corrientes filosóficas. Frente a este punto, Quijano da un giro a sus anteriores reflexiones para sostener ahora una oposición entre logos y mito en la cual el mito es la base para sostener la tesis de la racionalidad alternativa.

El segundo autor que desarrolla el concepto de mito es Zenón Depaz ${ }^{18}$. En líneas generales, este autor demuestra que el mito tiene una relación estrecha con la praxis colectiva y sirve como mediación para la cohesión de las multitudes. Además, Depaz complementa su análisis del mito a partir de sus implicaciones gnoseológicas que fueron fuente para las críticas al racionalismo, al positivismo y al cientificismo. La postura de Depaz sobre la dualidad logos/mito no posee una radical oposición, sino, como indicamos anteriormente, estos se encuentran imbricados: "No existe un límite preciso entre la razón y la fantasía. Existen hombres dotados de razón y fantasía, que hacen confluir en su vida cotidiana" (Depaz, 1991, p. 45). De modo que propone un carácter prospectivo del mito; a saber, "[1]a misión del mito no es estabilizar, sino dirigir la voluntad de los hombres hacia la acción transformadora" (Depaz, 1991, p. 45). Estas bases gnoseológicas del mito mariateguiano le permite a Depaz, como estamos viendo, reflexionar y desarrollar tópicos sobre filosofía política. El objetivo del mito, en tanto práctica política, tiene que poseer un sujeto político, así el mito cumple el rol de mediación entre la élite dirigente y las masas:

La capacidad del proletariado — sujeto portador del mito socialistade materializar el mito de la revolución social, depende de su capacidad de articular los intereses y aspiraciones de esa vasta gama popular [...] el mito toma cuerpo en una organización política cuya base social sean los trabajadores mismos, las fuerzas vivas de la sociedad 
civil; una organización política cuya estructura sea la expresión de la heterogeneidad de los sujetos parciales del bloque popular. (Depaz, 1991, p. 51)

En este punto concuerdo con Depaz en su análisis sobre el mito porque permite fundamentar una práctica política como mediación o, mejor dicho, articulación de distintos sectores sociales. Además, no subsume el concepto de mito a un análisis epistemológico, como vimos en el caso de Quijano. Igualmente, coincido en que el concepto de mito no es una característica secundaria o un rezago vitalista en el pensamiento de Mariátegui, sino que permite comprender sus implicaciones en la práctica política y social. Sin embargo, discrepo con Depaz respecto al marxismo abierto:

Tampoco estamos de acuerdo con que sea muestra de un "marxismo abierto". Consideramos que la incorporación de la categoría Mito es un caso típico de la capacidad de un marxismo cuyo eje es la práctica, para constituirse en un polo de gravitación teórica capaz, no de alearse a elementos de matriz teórica distinta, sino de asimilarlos al interior de la propia teoría redefiniendo su contenido conceptual. (1991, p. 39)

Salazar Bondy, contrariamente a la interpretación de Depaz, sostuvo que el marxismo abierto en Mariátegui se sitúa en la "[...] órbita del pensamiento marxista y no quiere salir de ella, porque reconoce como valor de dogmas vivos y en proceso de desarrollo" (1965, p. 312); en ningún momento lo caracterizó como una "aleación". Este marxismo abierto no propone subvertir su propio marco teórico, más bien esta crítica correspondería a Quijano, quien sostuvo dos influjos separados en Mariátegui: el pensamiento marxista y el pensamiento no marxista. Sin embargo, no se trata, como pretendió Quijano, de dos influjos teóricos separados; se trata más bien de que el pensamiento no marxista sea asimilado al marxismo de Mariátegui. Por tal motivo, queda refutado el argumento de Depaz porque para Salazar Bondy no hay una "aleación", sino un proceso de desarrollo en la trama teórica marxista en Mariátegui o, en otras palabras, una constante asimilación porque: "Mariátegui, sin esfuerzo ni remordimiento, aceptaba la posibilidad de que el marxismo, conservando intactas sus premisas materialistas, sea enriquecido y renovado mediante el aporte de otras doctrinas filosóficas" (Salazar Bondy, 2015, p. 60). 
Finalmente, en el marxismo abierto de Mariátegui encontramos un temprano distanciamiento con la fundamentación científica del marxismo, cuya matriz surgió en la tradición italiana con Benedetto Croce. Este filósofo planteó que el materialismo histórico no es una filosofía de la historia de carácter cientificista, como propuso un sector positivista, sino un nuevo método que sirve para analizar una determinada configuración social (Croce, 1942, p. 33). Por eso, a partir de la matriz marxista italiana de fines del siglo XIX ubicamos la crítica a la pretensión cientificista del marxismo que tuvo como uno de sus representantes en la década de 1960 a Louis Althusser ${ }^{19}$. En tal sentido, en el pensamiento mariateguiano ubicamos el carácter abierto de su marxismo que suscita, frente al inmovilismo teórico y político de posturas trasnochadas de la ortodoxia marxista, una propuesta propia en tanto creación heroica.

Por otro lado, a modo de complemento, tenemos la recepción de Friedrich Nietzsche en Mariátegui en torno al concepto de mito. La investigación de Ofelia Schutte denomina este influjo como marxismo nietzscheano e indica que "Mariátegui siguió la sana regla de incorporar las ideas de Nietzsche en un argumento marxista sin nombrar específicamente al filósofo alemán" (Schutte, 1992, p. 88). Esta incorporación del pensamiento nietzscheano en Mariátegui la ubicamos en los artículos "Dos concepciones de la vida", "El hombre y el mito" y "La lucha final" donde, según Schutte, se perciben las huellas implícitas del Nacimiento de la tragedia y Sobre la ventaja y desventaja de la historia para la vida. De modo que Nietzsche, en su obra juvenil, confrontaba el mito frente al hombre abstracto originado por la cultura moderna de la siguiente manera:

[...] toda cultura, si le falta el mito, pierde su fuerza natural sana y creadora: sólo un horizonte rodeado de mitos otorga cerramiento y unidad a un movimiento cultural entero. Sólo por el mito quedan salvadas todas las fuerzas de la fantasía y del sueño apolíneo de su andar vagando al azar. Las imágenes del mito tienen que ser los guardianes demónicos, presentes en todas partes sin ser notados, bajo cuya custodia crece el alma joven, y con cuyos signos se da el varón a sí mismo una interpretación de su vida y de sus luchas: y ni siquiera el Estado conoce leyes no escritas más poderosas que el fundamento mítico, el cual garantiza su conexión con la religión, su crecer a partir de representaciones míticas. 
Confróntese ahora con esto el hombre abstracto, no guiado por mitos, la educación abstracta, las costumbres abstractas, el derecho abstracto, el Estado abstracto: recuérdese la divagación carente de toda regla, no refrenada por ningún mito patrio, de la fantasía artística: imagínese una cultura que no tenga una sede primordial fija y sagrada, sino que esté condenada a agotar todas las posibilidades y a nutrirse mezquinamente de todas las culturas - eso es el presente, como resultado de aquel socratismo dirigido a la aniquilación del mito. (2014, p. 219)

Además, Schutte señala que no solo hubo una recepción teórica, sino que existió también una afinidad psicológica entre Mariátegui y Nietzsche, porque el marxismo nietzscheano en tanto "[...] espíritu revolucionario del marxismo está basado en la liberación inconsciente de la energía creativa, la cual es luego expresada en un compromiso consciente del ideal para una revolución social" (1992, p. 89). A diferencia de otras lecturas de Nietzsche, como la de los fascistas, Mariátegui canalizó y asimiló el vitalismo nietzscheano a su marxismo abierto. De modo que Schutte abre una vía de investigación poco explorada en la literatura mariateguiana y sostiene que Nietzsche no es una influencia periférica menor (Schutte, 1992, p. 91).

Hemos trazado de manera general, en un primer momento, la recepción de Nietzsche en Mariátegui. Ahora pasemos a delimitar con más precisión cómo el concepto de mito nietzscheano se inserta en la trama teórica del marxismo abierto de Mariátegui. Para tal propósito tenemos la investigación del filósofo David Cortez (2009), quien, al igual que Ofelia Schutte, señala que Nietzsche no es un recurso secundario para Mariátegui. Desarrolla así, a lo largo de su investigación, seis puntos sobre la relación Nietzsche-Mariátegui, entre los que rescato la afinidad entre ambos pensadores porque critican el historicismo moderno propuesto por tesis racionalistas y positivistas. De esta manera, Cortez sostiene que el mito salvaguarda

[...] el esencial carácter histórico del "animal metafísico" hombre; a partir de lo cual también se deduce la relatividad e historicidad de los mitos. Las tesis de Mariátegui sobre la relación mito e historia suponen una crítica a lecturas de la historia que se habían hecho desde cierto "marxismo ortodoxo". (2009, p. 155) 
Cortez ubica la recepción del concepto de mito nietzscheano en Mariátegui por medio de las obras: el Nacimiento de la tragedia y la Consideración intempestiva sobre la historia. Esta presencia del concepto de mito en ambos pensadores, según Cortez, garantiza un tipo de racionalidad histórica, que permite una crítica a los marxistas positivistas y evolucionistas; por tanto, “[...] en la perspectiva de una crítica histórica de la racionalidad moderna, Mariátegui retoma el mito desde una visión histórica del hombre. Su concepto de mito es un concepto histórico que polemiza con el racionalismo (Descartes) y el historicismo (Hegel)" (Cortez, 2009, p. 156). En tal sentido, siguiendo la argumentación de Cortez, el mito al poseer un carácter histórico está entonces relacionado con la concepción de los hombres y las sociedades en tanto productos históricos. Así, sostiene Cortez, Mariátegui “"[...] recurre a la idea del hombre como un ser insatisfecho con lo cual hace referencia a la condición de inacabado [...] en opinión de Mariátegui, la presencia del mito está vinculada directamente con la condición existencial del 'animal metafísico' hombre" (2009, p. 156). Esta conclusión en torno a la relación del mito y la historia es un aporte de Cortez a la literatura mariateguiana porque no solo analiza este concepto desde una perspectiva epistemológica, sino sugiere un análisis ontológico.

Además, Cortez señala a manera de crítica que la propuesta de la historia de Mariátegui se basa en una "cierta teleología inherente a la normatividad del paradigma socialista" porque "nunca renunció del todo al influjo de Hegel que lo vincula con una cierta filosofía del sujeto y que se encuentra en la base de sus reflexiones sobre la historia" (2009, p. 155). Si bien compartimos con Cortez que Mariátegui es un crítico del historicismo moderno, sin embargo, no concordamos con su señalamiento de un carácter teleológico en el pensador peruano. Ello debido a que la experiencia italiana ${ }^{20}$, y sobre todo Croce como vimos anteriormente, permitió a Mariátegui asumir el materialismo histórico como un método de interpretación de un contexto determinado, contrariamente a una filosofía de la historia de carácter teleológico, como sostuvieron varios marxistas ortodoxos. De modo que esta supuesta limitación de Mariátegui que asume Cortez como crítica no tiene sustento, pues Mariátegui rechaza el determinismo del historicismo y asimila el voluntarismo en su Defensa del marxismo ${ }^{21}$ : 
El carácter voluntarista del socialismo no es, en verdad, menos evidente, aunque sí menos entendido por la crítica, que su fondo determinista. Para valorarlo, basta, sin embargo, seguir el desarrollo del movimiento proletario, desde la acción de Marx y Engels en Londres, en los orígenes de la I Internacional, hasta su actualidad, DOMINADA por el primer experimento de Estado socialista: la U.R.S.S. En ese proceso, cada palabra, cada acto del marxismo tiene un acento de fe, de voluntad, de convicción heroica y creadora, cuyo impulso sería absurdo buscar en un mediocre y pasivo sentimiento determinista. (Mariátegui, 1981, p. 69)

Como indicamos anteriormente, Cortez nos abre el camino en torno al análisis ontológico de la obra de Mariátegui que parte del concepto de mito. Es decir, como un concepto que representa el núcleo de la praxis a manera de una movilización social en un nivel óntico. No obstante, quedaba en el aire ese fundamento que permitiría las condiciones de posibilidad de los mitos en la historia y que, a su vez, repercutiría en el estatus inacabado del hombre como veremos enseguida. Este primer paso delimitado a través del concepto de mito me permite proseguir hacia el análisis del concepto de agonismo para fundamentar lo que ha quedado entre líneas.

\section{La dimensión ontológica del agonismo mariateguiano}

En la trama teórica de Mariátegui, en tanto marxismo abierto, ubicamos una lectura sobre la obra de Miguel de Unamuno. Este filósofo español tuvo una recepción en el Perú no por sectores cristianos o católicos, sino por un marxista convicto y confeso como lo fue el pensador peruano. Si bien no son muchas las investigaciones sobre la relación Mariátegui-Unamuno, hoy en día cobran interés debido a la dimensión religiosa de su marxismo abierto; volveremos sobre este punto más adelante.

Anteriormente mostramos cómo la experiencia italiana fue asimilada teóricamente por Mariátegui y, además, estuvo al tanto de los sucesos europeos. En el caso de España, el pensador peruano cuestionó las medidas realizadas por el Directorio para socavar una actividad revolucionaria, cuya función fue " [...] sustituir, en la defensa del viejo orden social, la complicada y desgastada autoridad 
del gobierno representativo y democrático con la autoridad tundente del gobierno absoluto y autocrático" (Mariátegui, 1985, p. 121). Frente a esta situación, los intelectuales españoles criticaron y se opusieron al Directorio liderado por Miguel Primo de Rivera que representaba una dictadura, cuya consecuencia fue la represión y la persecución de los intelectuales. Uno de estos intelectuales fue Unamuno, quien fue retirado de su cátedra en la Universidad de Salamanca y deportado a la isla Fuerteventura (Islas Canarias) en febrero de 1924. Mariátegui, como vimos en una cita anterior, comprendió que esta medida política española representaba una posición reaccionaria frente a una posible superación del antiguo régimen. Y, en efecto, asumió una defensa en torno a los intelectuales españoles y específicamente se centró en la figura de Unamuno, a quien consideró una de las mayores inteligencias de Europa y caracterizó su filosofía como subjetivista y revolucionaria. Esta especificación como subjetivista se entiende como opuesta al realismo y naturalismo, si bien Mariátegui no nos da mayores detalles de estas acepciones filosóficas, no obstante se implica una adopción crítica hacia al positivismo que ya había asumido a través de su experiencia italiana. Y, en torno al atribuido carácter revolucionario, Mariátegui indica que se debe a la coyuntura política vivida frente a las medidas del Directorio que ha “ $[\ldots]$ empujado a Unamuno más marcadamente aún hacia la Revolución. Su repugnancia intelectual y espiritual a la reacción y a su despotismo opresor de la Inteligencia, lo había aproximado al proletariado y al socialismo" (1985, pp. 124-125).

Como complemento a este artículo de Mariátegui, la investigación de Antonio Melis nos ha permitido conocer la correspondencia entre Mariátegui y Unamuno. En una de sus pesquisas al Archivo Unamuno de Salamanca encontró una carta en la cual un grupo de intelectuales peruanos encabezado por Mariátegui expresa su solidaridad frente a la injusta deportación impuesta por Miguel Primo de Rivera:

Admirado y querido don Miguel:

Creo que nada de lo que su pensamiento y su vida susciten y engendren le puede ser indiferente. Le envío, por eso, estos papeles. Uno es el original de la protesta de los intelectuales peruanos contra su deportación. Acaso no sepa Ud. que quienes aquí representan la 
inteligencia y el espíritu estuvieron con Ud. entonces. Y ninguno de estos testimonios de solidaridad y admiración debe faltarle

Devotamente lo saluda.

José Carlos Mariátegui. (Melis, 1989, p. 131)

Ello nos permite comprender que la relación Mariátegui-Unamuno no solo fue un vínculo teórico, sino que también hubo una estrecha amistad personal entre ambos pensadores. Esta relación intelectual para muchos se torna paradójica porque a primera vista parece que ambos tienen más diferencias teóricas y políticas que similitudes. Pero veremos que solo es una línea delgada, ya que Mariátegui asimila el concepto de agonismo de Unamuno.

Ahora bien, en el contexto de la dictadura de Primo de Rivera (19231930), el filósofo español, ya deportado, pudo escapar hacia la ciudad de París, lugar donde escribió La agonía del cristianismo, publicado en 1925. En el prólogo del libro señala que su escritura tuvo un rasgo vivencial debido a su situación de inmigrante; esto permite trazar el hilo conductor de la obra, a saber, la condición existencial de la agonía frente a la vida:

Los dogmáticos son los que monologan, y hasta cuando parecen dialogar, como los catecismos, por preguntas y respuestas. Pero los escépticos, los agónicos, los polémicos, no monologamos. Llevo muy en lo dentro de mis entrañas espirituales la agonía, la lucha, la lucha religiosa y la lucha civil, para poder vivir de monólogos. Job fue un hombre de contradicciones, y lo fue Pablo, y lo fue Agustín, y lo fue Pascal, y creo serlo yo. (Unamuno, 2007, p. 23)

Unamuno define el concepto de agonía a partir de la palabra griega ảyóv (agón) cuyo significado es lucha, pero no es una lucha sin más porque el filósofo español precisa que vive en tanto está luchando. Es decir, hay una imbricación entre la lucha y la vida como las dos caras de una moneda: "Se habla de struggle for life, de lucha por la vida; pero esta lucha por la vida es la vida misma. La life, y es a la vez la lucha misma, la struggle" (Unamuno, 2007, p. 27). Por tanto, infiere Unamuno, siendo cristiano, que su lucha es una lucha por el cristianismo, que representa la agonía de este. 
Ahora bien, Unamuno - como vemos- sostiene la agonía de un nivel particular; no obstante este primer nivel pasa a uno general a través de la discordia porque "[...] lo que más une a los hombres unos con otros son nuestras discordias. Y lo que más le une a cada uno consigo mismo, lo que hace la unidad intima de nuestra vida, son nuestras discordias íntimas" (2007, p. 29). En este punto observamos que Unamuno implica la discordia como efecto de la agonía, enlazando un plano existencial hacia lo social. Por ello, como muestra de estos dos niveles, Unamuno representa este primer nivel con la figura de Jesucristo, porque trajo la lucha y, en efecto, el cristianismo sería el segundo nivel porque a lo largo de su historia lo caracteriza agónicamente.

A partir de estas conclusiones, Unamuno hará una relectura del cristianismo como agonismo, mas no como una doctrina de carácter cerrada y fosilizada. De modo que el filósofo español utiliza el concepto de cristiandad, en vez de cristianismo, para recuperar la cualidad del ser cristiano: "[e]se fatídico sufijo - ismo, cristian-ismo - lleva a creer que se trata de una doctrina como platonismo, aristotelismo, cartesianismo, kantismo, hegelianismo. Y no es eso. Tenemos, en cambio, una hermosa palabra, cristiandad, que, significando propiamente la cualidad de ser cristiano" (Unamuno, 2007, p. 36). Asimismo, realiza una distinción entre verbo y letra que le sirve como estrategia conceptual para asumir que el cristianismo en un inicio fue un agonismo representado en el "verbo", pero que luego se convirtió en "letra" a través de la doctrina del Evangelio. Dicho verbo también es representado por la vida de Jesucristo, porque después de su muerte

[...] la carne se hizo esqueleto, la palabra se hizo dogma, y las aguas del cielo fueron lavando los huesos del esqueleto y llevándose a la mar sus sales. Que es lo que ha hecho la exégesis de origen protestante, la exégesis de los de la Letra, de los del Libro. Porque el espíritu, que es palabra, que es verbo, que es tradición oral, vivifica, pero la letra, que es el libro, mata. (Unamuno, 2007, p. 44)

Pero el cristianismo o, mejor dicho, la doctrina en cuanto "letra" arguye Unamuno - está en constante contradicción al convertirse en dogma, porque “[...] el dogma vivía de las herejías como la fe vive de dudas. El dogma se 
mantenía de negaciones y se afirmaba por negaciones" (2007, p. 49). Finalmente, acorde con los planteamientos de La agonía del cristianismo, Unamuno concluye que el contexto político español ha despertado su agonía. De esto resulta necesario admitir que Unamuno plantea dos puntos centrales que nos servirán para enlazar con Mariátegui. En primer lugar, el filósofo español sostiene que los dogmáticos son los que monologan, refiriéndose a la actividad teórica, que Mariátegui compartiría a través de su marxismo abierto que asimila diversos aportes en su trama teórica. En segundo lugar, Unamuno traza una genealogía de agonistas a partir de referentes cristianos que suscitará una polémica con Mariátegui en torno a Marx, pues el pensador peruano considera que el filósofo alemán también representa a un agonista en esta genealogía.

Habíamos mencionado anteriormente que Mariátegui, mediante un artículo, se ocupó de la deportación del filósofo español y además mandó una carta haciéndole saber su solidaridad frente a esta situación. Posteriormente, Mariátegui realiza una reseña al libro La agonía del cristianismo de Miguel de Unamuno $^{22}$. En este texto no encontramos un amplio análisis teórico ni formulación sistemática en torno al concepto de agonismo, pues solo se trata de un breve ensayo a manera de reseña. No obstante, frente a esta situación, asumiremos una labor interpretativa para llevar a cabo un análisis pormenorizado cuya finalidad es retomar dicho concepto en diálogo con la filosofía contemporánea.

Mariátegui señala en su reseña que Unamuno restaura el verdadero significado de agonía como lucha, y considera que "[e]sta concepción de la vida que contiene más espíritu revolucionario que muchas toneladas de literatura socialista nos hará siempre amar al maestro de Salamanca” (1985, p. 120). En estas primeras líneas, vemos que Mariátegui asimila este concepto a su marxismo abierto porque le permite recobrar el carácter revolucionario, a diferencia de la fosilizada literatura socialista. La asimilación de esta matriz de pensamiento religioso cristiano es, incluso hoy día, problemática porque se considera que el marxismo es contrario a toda reflexión religiosa — lo mismo sucede con el concepto de mito-. Michael Löwy, respecto a este punto, ubica 
en Mariátegui un "momento irreductiblemente romántico" que le permite insertar la dimensión religiosa al socialismo: “[...] el aporte más original e innovador de Mariátegui a la reflexión marxista sobre la religión es su hipótesis acerca de la dimensión religiosa del socialismo, su análisis de las afinidades electivas [...] entre mística revolucionaria y fe cristiana" (2010, pp. 58-59). En este mismo tenor, Pierina Ferretti realiza una aguda y minuciosa investigación del corpus teórico de Mariátegui para concluir que, siguiendo la tesis de Ernst Bloch, “[...] la religiosidad será una actitud, una disposición espiritual al heroísmo, a la lucha, a la fe, que no contiene elementos trascendentes sino que se mueve completamente en el plano de la inmanencia y de la historia" (2017, p. 65). La autora agrega que la lectura religiosa del marxismo en Mariátegui es “[...] una lectura 'materialista' de la religión: no hablamos de materialismo metafísico, sino de uno radicalmente histórico. Mariátegui en ningún momento adscribe a una concepción extra-histórica cuando alude a la religiosidad del marxismo y de los procesos revolucionarios" (Ferretti, 2017, p. 66).

La recepción del pensamiento de Unamuno en Mariátegui, según vimos, ha tenido un rol importante en su trama teórica porque transferirá al marxismo la herejía o la dimensión crítica ${ }^{23}$ representada por la agonía del cristianismo. El pensador peruano conocía la propuesta teórica de Croce y Sorel frente a las lecturas fosilizadas del marxismo ortodoxo, entonces inferimos que Mariátegui considera que Unamuno forma parte de esta misma tradición crítica. La investigación de Osvaldo Fernández exhorta hasta este punto que no debemos sostener un esquema simple sobre la influencia de Unamuno en Mariátegui, como si tal "[...] esquema [leyera] la influencia como una filiación directa, dejando entender que lo que dice Unamuno se repite en Mariátegui, y que basta con reemplazar cristianismo por marxismo, para entender el influjo" (2010, p. 145). El argumento del mariateguista chileno es que encontramos tres niveles de lectura en Mariátegui: a) el primero en torno a la experiencia personal de Unamuno con el cristianismo; b) el segundo traduce el concepto de agonía en una propia problemática frente al marxismo; y, a partir de estos dos niveles de lectura — según Fernández- encontramos un tercer nivel donde: 
Mariátegui encontrará, en un recodo del camino, los criterios con que Unamuno revisa su experiencia cristiana. Lo que se anuncia como una anticipación, embrionaria de lo que será la "propia y personal agonía de su marxismo", o sea la revisión de su propia experiencia teórica marxista. (2010, p. 147)

Estos tres niveles planteados por Fernández permiten hacer una lectura en clave hermenéutica sobre el concepto de agonía, que explica la disputa de Mariátegui frente a otras lecturas sobre Marx. "La producción de Mariátegui señala Fernández-, como toda producción es creación de algo nuevo, diferente. Su acto anuncia ya la heterodoxia que definirá lo especifico de su manera de pensar" (2010, p. 148). Este abordaje del mariateguista chileno permite comprender con detalle la crítica de Mariátegui a la lectura de Unamuno sobre Marx. El pensador peruano sostiene que el filósofo español tiene una interpretación equivocada del marxismo:

La vehemencia política lleva aquí a Unamuno a una aserción arbitraria y excesiva. No; no es cierto que Karl Marx creyese que las cosas hacen a los hombres. Unamuno conoce mal el marxismo. La verdadera imagen de Marx no es la del monótono materialista que nos presentan sus discípulos. A Marx hace falta estudiarlo en Marx mismo. Las exégesis son generalmente falaces. Son exégesis de la letra, no del espíritu. (Mariátegui, 1985, p. 118)

La estrategia de Mariátegui es, como primer paso, asimilar los recursos hermenéuticos propuestos por Unamuno para, como segundo paso, cuestionar a través de esta asimilación la lectura unamuniana sobre Marx. Como anotamos anteriormente, el filósofo español hace una relectura a partir del concepto de agonismo sobre el cristianismo donde concluye que ha recaído en la "letra", es decir, en el dogma. Por eso, Mariátegui exhorta a Unamuno a que utilice esta misma estrategia hermenéutica para analizar la obra de Marx:

Marx no está presente, en espíritu, en todos sus supuestos discípulos y herederos. Los que lo han continuado no han sido los pedantes profesores tudescos de la teoría de la plusvalía, incapaces de agregar nada a la doctrina, dedicados sólo a limitarla, a estereotiparla; han sido, más bien, los revolucionarios, tachados de herejía, como Georges Sorel —otro agonizante diría Unamuno - que han osado enriquecer y desarrollar las consecuencias de la idea marxista. (1985, p. 119) 
En este contexto, Mariátegui ya conocía las disputas sobre el materialismo histórico marxista en su experiencia italiana. Como consecuencia, el pensador peruano cuestionaba las perspectivas racionalistas y positivistas del marxismo ortodoxo, a diferencia de Unamuno que generalizó en bloque el marxismo sin realizar distinción alguna. El filósofo español respondió a la crítica de Mariátegui mediante una carta personal. En esta misiva no ahonda ni desarrolla la crítica del pensador peruano, pero realiza algunas concesiones frente a Mariátegui y se rectifica indicando lo siguiente:

\begin{abstract}
Sí, en Marx había un profeta; no era un profesor. (Y vea Ud. cómo estos dos términos, profesor y profeta, latino el uno y el otro griego, que etimológicamente son parientes, han venido a significar cosas tan distintas y hasta opuestas. Mucho de mi vida íntima ha sido un oficio contra el oficio oficial, contra la profesoría académica). (En Mariátegui, 1984, p. 195)
\end{abstract}

Este episodio cobró interés en Alberto Flores Galindo quien, en plena polémica sobre el legado de Mariátegui en el Perú, publicó su libro La agonía de Mariátegui en 1979. Este historiador peruano estudia y desarrolla la actividad política de Mariátegui durante las polémicas con el APRA y con la Komintern ${ }^{24}$ para demostrar el agonismo político de Mariátegui. Así, Flores Galindo señala que el verbo "agonizar" es la "llave del mariateguismo" porque "nos abre al mundo de su tensión interna” (1994, pp. 390-391). Aunque consideramos que este historiador peruano al enunciar dicha "tensión interna" ya preconcebía, o preconfiguraba, el conflicto interno del agonismo en un sentido ontológico; es decir, dentro de un conflicto interior o agonal en un nivel ontológico. Sin embargo, se centrará solamente en las polémicas políticas en las cuales se insertó Mariátegui.

En resumen, por un lado Fernández ha propuesto el concepto de agonismo como recurso hermenéutico marxista y, por otro, Flores Galindo ha demostrado sus efectos prácticos en la vida política de Mariátegui. Estas dos investigaciones han aportado al análisis y problematización del concepto de agonía. Sin embargo mi investigación tomará una vía diferente porque trasladaré este análisis y problematización hacia una reflexión ontológica. En este punto 
retomaremos la propuesta del posfundacionalismo de Oliver Marchart, quien a partir de Heidegger sostiene que "[...] la ausencia del fundamento es propia de la naturaleza de un abismo, vale decir, de un fundamento $\sin$ fundamento, de un fundamento sin fondo" (2009, p. 34). De manera que este fundamento sin fundamento último es representado por el Abgrund, es decir, un abismo que imposibilitaría un fundamento último. A partir de este punto, Marchart apertura una nueva vía frente al fundacionalismo, que sostiene un fundamento trascendente, y al antifundacionalismo, que niega algún fundamento y rige el "todo vale" del posmodernismo.

El posfundacionalismo, al tratar sobre el fundamento, adopta la perspectiva de la diferencia ontológica heideggeriana: entre el nivel óntico de los entes y el nivel ontológico del ser. Ello le permite a Marchart, en tanto recurso teórico, trasladarlo en la distinción entre "la política" como prácticas políticas en un nivel óntico, y "lo político" 25 como dimensión ontológica de institución de la sociedad. Tras haber delimitado de manera breve el campo teórico del posfundacionalismo, sostengo que el concepto de agonismo en Mariátegui se ubicaría en una dimensión ontológica por las siguientes razones: a) el agonismo como fundamento ontológico posibilita los efectos ónticos estudiados por Flores Galindo y los efectos hermenéuticos como anotó Fernández; b) el agonismo en tanto lucha infiere no un fundamento último, sino un inacabamiento no esencialista del hombre. De manera que el agonismo mariateguiano permite sostener la incompletud ontológica del sujeto, como sostienen varios exponentes de la filosofía política contemporánea (como Ernesto Laclau, Chantal Mouffe — véase infra-y Santiago Castro-Gómez). A propósito, y volviendo a Nietzsche, CastroGómez $^{26}$ retoma como argumento el agonismo nietzscheano para confrontar la crítica de Žižek a Foucault: a saber, la propuesta foucaultiana reduce al sujeto como mero producto de las relaciones de poder sin percatarse de un antagonismo fundamental. Por el contrario, el filósofo colombiano sostiene que sí encontramos una ontología del poder a través del agonismo representado en la voluntad de poder de Nietzsche, pues ubica en los fragmentos póstumos del pensador alemán 
“[...] una trasposición ontológica de aquellas reflexiones del joven Nietzsche en torno al agonismo de los griegos" (Castro-Gómez, 2015, p. 228). Así, concluye que el agonismo no es una sustancia, sino una multiplicidad de fuerzas en constante conflicto (Castro-Gómez, 2015, p. 230); tampoco debemos confundirlo con fenómenos físicos, psíquicos, políticos o sociológicos, pues las relaciones de fuerzas tienen una dimensión ontológica (Castro-Gómez, 2015, p. 235). Este análisis del agonismo nietzscheano realizado por Castro-Gómez permite presentar otras matrices filosóficas en el debate de la filosofía política contemporánea. Y, en consecuencia, facilita también insertar la propuesta del marxismo abierto de Mariátegui.

Para concluir debo señalar que a lo largo de este artículo se han desarrollado los conceptos de mito y agonismo con el fin de demostrar la vigencia de la obra de José Carlos Mariátegui. No en el sentido de repetir lo ya dicho como una exégesis, sino avanzar propositivamente a través del legado mariateguiano o, dicho de otra manera, ir con Mariátegui, más allá de Mariátegui.

\section{Notas}

1 Para más detalles históricos sobre la experiencia italiana del Amauta véase el prólogo de Estuardo Núñez en Cartas de Italia; también, "La formación de un revolucionario" de Malcolm Silvers (1981) y "El marxismo de Mariátegui” de Robert Paris (1973).

2 Este pensador peruano, natural de Moquegua, realizó una labor periodística que le permitió ser conocido precozmente en la intelectualidad limeña durante la primera década del siglo XX. A los 25 años de edad fundó el diario La Razón y desde esa plataforma escrita se opuso al gobierno de Augusto B. Leguía. Este, a manera de estrategia, con la finalidad de tenerlo lejos del país, le concede una beca a Italia (Rouillón, 1963).

3 También tenemos Cartas de Italia, una publicación póstuma realizada por los hijos de Mariátegui, que consta de artículos publicados durante la experiencia europea, específicamente entre 1920 y 1922. En este libro encontramos diversos artículos sobre los avatares políticos del Partido Socialista Italiano que posteriormente, en 1921, por medio de una escisión encabezada por Amadeo Bordiga y Antonio Gramsci, se convierte en el Partido Comunista Italiano.

4 Friedrich Engels, que tuvo un conocimiento de la situación política de su época, consideraba que el Partido Socialista Italiano era un partido débil y confuso, aunque reconocía la constante actividad que realizaban sus militantes. Luego tuvo conocimiento de la obra de Labriola, a partir de lo cual lo consideró como un principal teórico marxista en Italia (Kohn, 1986). 
5 A propósito de este punto, Carlos Kohn indica que Labriola no asumió la estrecha dicotomía entre estructura y superestructura que asumían mayormente el sector de los marxistas ortodoxos, sino consideraba que estas no poseían límites y se integraban; además, precisa que "Labriola, por el contrario, intenta evitar, por principio, y en lo posible, el término 'superestructura', de manera que incluso cuando cita textualmente el conocido párrafo del Prefacio a la Contribución a la crítica de la economía política emplea para el término Überbau, el feo neologismo 'sobreestrucción' (soprastruzione), neologismo que, de todas formas, utiliza poquísimas veces” (Kohn, 1986, p. 35).

6 Esta actitud de revisionismo frente al marxismo fue compartida por Croce. Ello permitió afianzar una amistad entre ambos filósofos que, incluso, publican su correspondencia en La Crítica, revista dirigida por Croce, donde trataban temáticas filosóficas.

7 La recepción de la obra Croce en el Perú no se inicia con Mariátegui. Previamente Alejandro Deustua, considerado como uno de los fundadores de la filosofía en América Latina, escribió sobre este filósofo italiano, incluso le dedica un capítulo en su libro Estética general (1923). No hemos encontrado un debate entre ambos en torno a Croce porque, por un lado, Deustua se centrará más en los estudios estéticos y, por otro, Mariátegui asimiló premisas sobre el materialismo histórico croceano. Sin embargo, Mariátegui será un crítico tenaz de la propuesta educativa de Deustua porque "[...] encarnaba, bajo un indumento universitario y filosófico de factura moderna, la mentalidad del civilismo feudal, de los encomenderos virreinales" (Mariátegui, 2012, p. 162).

8 Mariátegui, en Defensa del marxismo, sostiene una máxima croceana - como veremos más adelante-: "El materialismo histórico no es, precisamente, el materialismo metafísico o filosófico, ni es una Filosofía de la Historia, dejada atrás por el progreso científico. Marx no tenía por qué crear más que un método de interpretación histórica de la sociedad actual" (Mariátegui, 1981, p. 40). Por otro lado, Robert Paris sostiene que "[l] os azares de su biografía, su matrimonio con Anna Chiappe, hacen que Mariátegui se haya introducido cerca del filósofo Benedetto Croce, amigo de sus padres políticos" (Paris, 1973, p. 9). Si bien es incuestionable la influencia de Croce, no obstante Mariátegui no es un croceano sin más, sino aquel representa un recurso en la trama teórica del pensador peruano.

9 En algunas investigaciones sobre Croce traducen la palabra italiana "canone" por "canon", que refiere a un conjunto de reglas y normas. En cambio, Mariátegui le asigna el significado filosófico de "método", en tanto procedimiento para la búsqueda de la verdad. De este modo, inferimos que Mariátegui cuando adopta el materialismo histórico como método de interpretación no pretende caer en un burdo relativismo hermenéutico, sino que su objetivo es proponer un análisis de la realidad peruana para defenderlo en tanto verdad frente a las lecturas criollas e hispanistas.

10 Actualmente se realizan investigaciones sobre Benedetto Croce y Walter Benjamin, véase el artículo de Axel Körner: "The Experience of Time as Crisis. On Croce's and Benjamin's Concept of History” (2011).

11 Las críticas realizadas por Gramsci fueron compiladas en el libro El materialismo 
histórico y la filosofía de Benedetto Croce (1975). El corto espacio de este estudio no me permite hacer mayores comentarios que permitan mostrar las similitudes y diferencias entre Gramsci y Mariátegui frente a la lectura de Croce.

12 "Si Mariátegui pudo dar de la doctrina de Marx una interpretación tendencialmente antieconomicista y antidogmática en una época en que intentarla desde las filas comunistas era teóricamente inconcebible y políticamente peligrosa, sólo fue posible merced al peso decisivo que tuvo en su formación la tradición idealista italiana en su etapa de disolución provocada por la quiebra del estado liberal y el surgimiento de corrientes crocianas 'de izquierda' y marxistas revolucionarias. Mariátegui leyó a Marx con el filtro del historicismo italiano y de su polémica contra toda visión trascendental, evolucionista y fatalista del desarrollo de las relaciones sociales, característica del marxismo de la II Internacional" (Aricó, 1980, pp. XIV-XV).

13 En una reciente publicación de Segundo Montoya Huamaní (2018) se retoma la noción de marxismo abierto para sostener "la apertura epistemológica crítica". Ello le permite dialogar y cuestionar algunas interpretaciones sobre Mariátegui realizadas por Aníbal Quijano, David Sobrevilla, Enrique Dussel, Raúl Fornet Betancourt, entre otras personalidades.

14 Este personaje no tuvo parentesco familiar con Antonio Labriola, pero sí participó activamente en el ambiente socialista y sindicalista italiano. Viajó a Francia debido a la persecución de que fue objeto por su participación en las huelgas realizadas durante mayo de 1898 en Milán. En este exilio francés entabló amistad con Georges Sorel.

15 Otro punto de encuentro entre Mariátegui y Gramsci es la búsqueda del sujeto histórico a través de una alianza entre el proletariado y los indígenas, en el caso peruano, y la propuesta de la voluntad colectiva, en el caso italiano. Ello debido al similar contexto sociopolítico que vivieron ambos pensadores en donde no hubo un desarrollo industrial, solo un incipiente capitalismo.

16 Este concepto de "método de interpretación" también se hace presente como título en 7 ensayos de interpretación de la realidad peruana. En la advertencia de este libro, Mariátegui hace hincapié en que sus ensayos no representan una doctrina cerrada sobre la realidad nacional, sino son inacabados: "Volveré a estos temas cuantas veces me lo indique el curso de mi investigación y mi polémica. Tal vez hay en cada uno de estos ensayos el esquema, la intención de un libro autónomo. Ninguno de estos ensayos está acabado: no lo estará mientras yo viva y piense y tenga algo que añadir a lo por mí escrito, vivido y pensado" (2012, p. 42).

17 La lectura de Quijano sobre La crítica a la razón instrumental de Theodor Adorno y Max Horkheimer es fundamental en esta propuesta de imbricación entre logos/mito como vimos en párrafos anteriores. Sin embargo, se distancia del planteamiento de la razón instrumental para sostener la racionalidad alternativa, pero no se trata de una superación dialéctica, sino de encontrar una racionalidad alternativa universal. De este modo, Quijano desplaza este debate europeo al ámbito latinoamericano y será una de las bases de su posterior propuesta teórica sobre la colonialidad del poder. Queda 
pendiente ahondar en esta investigación para cuestionar las propuestas esencialistas y conservadoras derivadas del "pensamiento decolonial".

18 El artículo de Depaz (1991) es un texto editado de su tesis de bachiller "Bases gnoseológicas de la categoría mito en la obra de José Carlos Mariátegui”, que fue sustentada en la Universidad Nacional Mayor de San Marcos en 1989.

19 Althusser en Pour Marx (1969) nos indica que en la producción teórica del filósofo alemán observamos una ruptura epistemológica a partir de la Ideología alemana (1845). De modo que encontramos un Marx "ideológico" (conocido como la etapa del "joven Marx": Manuscritos de 1844 y la Sagrada familia) y un Marx "científico" (dividido en obras de maduración: Manifiesto comunista, Miseria de la filosofía, etcétera; y obras de la madurez: El Capital). En tal sentido, Althusser postula que Marx funda el materialismo histórico como ciencia y el materialismo dialéctico como filosofía, este último desarrollado por Engels y Lenin.

20 Ya hemos desarrollado la experiencia italiana de Mariátegui. Por tal motivo, inferimos que no solo fue Nietzsche el que lo despertó del sueño dogmático sobre el racionalismo y el historicismo, sino también los filósofos italianos.

21 Cuando se habla de una "defensa del marxismo" pareciera implicarse la defensa de una lectura ortodoxa marxista. Por el contrario, en la obra mencionada encontramos la defensa del marxismo abierto de Mariátegui. Es decir, se trata de una defensa de $s u$ marxismo, diferente a las lecturas ortodoxas de su época. A propósito, en sintonía con este punto, Osvaldo Fernández señala que: "Mariátegui, desde esta perspectiva absolutamente local, [inserta y adecua] el marxismo en la realidad latinoamericana. Quizás, por primera vez en América Latina, el marxismo es pensado a propósito de esta realidad anclada en un aquí y ahora precisos, pues en la misma medida que se usa el marxismo como el instrumento del análisis de esta realidad, se modifica tanto la realidad como el instrumento" (2015, p. 116).

22 Como ya habíamos mencionado, Mariátegui lee esta obra en su primera edición francesa (París: Editorial F. Rieder, 1925). Además, gracias a la investigación del norteamericano Harry Vanden (1975) tenemos registro de que el pensador peruano tuvo en su biblioteca Del sentimiento trágico de la vida (Madrid: Renacimiento, [1912]) y la Vida de Don Quijote y Sancho (Madrid: Renacimiento, 1928).

23 La dimensión de la crítica en el marxismo ha permitido un desarrollo teórico en algunos filósofos. Por ejemplo, tenemos a Bolívar Echeverría que empleó el "discurso crítico" para sostener que el marxismo es una constante actividad de perfeccionamiento y de elaboración teórica frente al capitalismo, a manera de una "acción desestructuradora" (1986, p. 50). Por tanto, se puede deducir que la noción de "discurso crítico" guarda similitudes con el marxismo abierto, por lo que habría que ahondar en estas nociones para precisar tales similitudes.

24 Flores Galindo estudia la I Conferencia Comunista realizada en Buenos Aires durante el mes de junio de 1929. Mariátegui no pudo viajar a este evento por su delicada salud — falleció al año siguiente-, pero Julio Portocarrero y Hugo Pesce asistieron 
en representación del Partido Socialista Peruano. Estos dos delegados disertaron sobre "El problema de las razas en América Latina" y "Punto de vista antiimperialista", documentos redactados por Mariátegui. El argentino Vittorio Codovilla, quien fue organizador de este foro, e intermediario de la Komintern, tuvo una mala impresión de estas intervenciones, pues su razonamiento marcado por un determinismo abogaba por una revolución democrático-burguesa para el advenimiento del comunismo. Por el contrario, los documentos presentados por los peruanos no asumían dicha propuesta y buscaban a través de la alianza obrera y campesina (conformada por indígenas) una revolución socialista. Incluso, más adelante, las críticas vinieron desde la Unión Soviética; estas consideraron a Mariátegui como un mero populista. Véase el estudio ‘El ‘populismo' en el Perú. El papel de Mariátegui en la historia del pensamiento social latinoamericano" de V. M. Miroshevski, que fue compilado por José Aricó en Mariátegui y los orígenes del marxismo latinoamericano (1980).

25 Esta distinción será el hilo conductor de Marchart para designar como heideggerianos de izquierda a autores como Jean-Luc Nancy, Claude Lefort, Alain Badiou y Ernesto Laclau. Aquel dedicará extensos capítulos para demostrar su inicial hipótesis. Mi investigación no tiene como propósito forzar la denominación de posfundacionalismo a la obra de Mariátegui, sino retoma el agonismo a través de estas reflexiones filosóficas contemporáneas, a manera de ir "más allá de Mariátegui".

26 La obra de este filósofo colombiano ha tenido una importante repercusión en el debate filosófico latinoamericano. Se le considera uno de los más destacados estudiosos de la obra de Michel Foucault y a partir de este bagaje filosófico ha realizado una respuesta a las críticas vertidas por Slavoj Žižek en torno al historicismo posmoderno. Además, el filósofo colombiano, a través de Ernesto Laclau, Chantal Mouffe y Enrique Dussel, se opone a la crítica de Žižek respecto a la democracia. Véase con más detalle Revoluciones sin sujeto. Slavoj Žižek y la crítica del historicismo posmoderno (2015).

\section{Referencias bibliográficas}

Althusser, L. (1969). La revolución teórica de Marx [traducción de Pour Marx, 1965]. 4a . ed. Ciudad de México: Siglo XXI Editores.

Arico, J. (1980). Mariátegui y los orígenes del marxismo latinoamericano. Ciudad de México: Ediciones Pasado y Presente.

Beigel, F. (2005). Una mirada sobre otra: el Gramsci que conoció Mariátegui. Estudos de Sociologia, 10(18-19), 23-49. Recuperado de https:// periodicos.fclar.unesp.br/estudos/article/view/113/110.

Castro-Gómez, S. (2015). Revoluciones sin sujeto. Slavoj Žižek y la crítica al historicismo posmoderno. Madrid: Akal.

Cortez, D. (2009). Nietzsche y Dionisos en Latinoamérica. Discursos de 
identidad, mito y modernidad. Saarbrücken: Suedwestdeutscher Verlag fuer Hochschulschriften.

Croce, B. (1942). Materialismo histórico y economía marxista. Buenos Aires: Ediciones Imán.

Depaz, Z. (1991). La categoría mito en la obra de Mariátegui. Anuario mariateguiano, 3 (3), 32-55.

Deustua, A. (1923). Estética general. Lima: Eduardo Ravago.

Echeverría, B. (1986). El discurso crítico de Marx. Ciudad de México: Era.

Fernández, O. (2010). Itinerario y trayectos heréticos de José Carlos Mariátegui. Santiago de Chile: Editorial Quimantú.

Fernández, O. (2015). ¿Defensa o transformación del marxismo? En J. C. Mariátegui. Defensa del marxismo. Edición comentada. Valparaíso: Centro de Estudios del Pensamiento Iberoamericano-Universidad de Valparaíso.

Ferretti, P. (2017). La dimensión religiosa en la obra de José Carlos Mariátegui. Del misticismo decadentista a la religiosidad revolucionaria. Utopía y Praxis Latinoamericana, 22(77), 57-66. Recuperado de https://www. redalyc.org $/ \mathrm{html} / 279 / 27952380007 /$

Flores Galindo, A. (1994). Obras completas. Tomo II: Apogeo y crisis de la República aristocrática/La agonía de Mariátegui. Lima: Sur Casa de Estudios del Socialismo.

García Salvatecci, H. (1979). Sorel y Mariátegui. Lima: Editorial Enrique Delgado Valenzuela.

Gramsci, A. (1975). El materialismo histórico y la filosofía de Benedetto Croce. Ciudad de México: Juan Pablos.

Gramsci, A. (1980). Cuadernos de la cárcel, tomo 5. Edición crítica del Instituto Gramsci a cargo de Valentino Gerratana. Ciudad de México: Era.

Kohn, C. (1986). Antonio Labriola: Orígenes de la perspectiva teórica-metódica del marxismo en Italia. En Perfiles del marxismo I. La filosofía de la praxis: de Labriola a Gramsci (17-64). Caracas: ALFAIL Ediciones. 
Körner, A. (2011). The Experience of Time as Crisis. On Croce's and Benjamin's Concept of History. Intellectual History Review 21(2), 151-169.

Labriola, A. (s/f). Filosofía y socialismo. Introducción al conocimiento de la historia desde el punto de vista marxista. Buenos Aires: Claridad.

Labriola, A. (1945). Del materialismo histórico. Dilucidación preliminar. Buenos Aires: Editorial Intermundo.

Labriola, A. (1961). En memoria del Manifiesto Comunista. En Biografia del Manifiesto Comunista (297-356). Ciudad de México: Compañía General de Ediciones, S.A.

Löwy, M. (2010). Comunismo y religión. La mística revolucionaria de José Carlos Mariátegui. Utopía y Praxis Latinoamericana, 10(28), 49-59.

Marchart, O. (2009). El pensamiento politico posfundacional: la diferencia política en Nancy, Lefort, Badiou y Laclau. Ciudad de México: Fondo de Cultura Económica.

Mariátegui, J. C. (1969). Cartas de Italia. Lima: Empresa Editora Minerva S. A.

Mariátegui, J. C. (1972). El hombre y el mito. En El alma matinal (23-28). Lima: Empresa Editora Minerva S. A.

Mariátegui, J. C. (1981). Defensa del marxismo. Lima: Empresa Editora Minerva S. A.

Mariátegui, J. C. (1984). Correspondencia. Lima: Empresa Editora Minerva S. A.

Mariátegui, J. C. (1985). Signos y obras. Lima: Empresa Editora Minerva S. A.

Mariátegui, J. C. (2012). 7 ensayos de interpretación de la realidad peruana. Ideología y política. Colección Mariátegui Total, Tomo I. Lima: Empresa Editora Minerva S. A.

Marini, G. (2012). Il rapporto Sorel-Labriola dentro e fuori il marxismo. Crítica marxista. Analisi e contributi per ripensare la sinistra, 1, 67-76.

Marx, K. (1982). Escritos juveniles. Ciudad de México: Fondo de Cultura Económica.

Melis, A. (1989). Una esquela de Mariátegui. Anuario mariateguiano, 1(1), 131. 
Meseguer, D. (1974). José Carlos Mariátegui y su pensamiento revolucionario. Lima: Instituto de Estudios Peruanos.

Montoya, S. (2018). Conflictos de interpretación en torno al marxismo de Mariátegui. Lima: Heraldos Editores.

Nietzsche, F. (2014). Del nacimiento de la tragedia. Madrid: Alianza Editorial.

Núñez, E. (1969). Prólogo. En J. C. Mariátegui, Cartas de Italia. Lima: Empresa Editora Minerva S. A.

Paris, R. (1973). El marxismo latinoamericano de Mariátegui. Buenos Aires: Ediciones de Crisis.

Quijano, A. (1981). Reencuentro y debate. Una introducción a Mariátegui. Lima: Mosca Azul Editores.

Quijano, A. (1986). La tensión del pensamiento latinoamericano. Hueso Húmero, 22, 106-113.

Quijano, A. (1988). Modernidad, identidad y utopía en América Latina. Lima: Sociedad y Política Ediciones.

Quijano, A. (1995). El marxismo en Mariátegui: una propuesta de racionalidad alternativa. En Sobrevilla, D. V Congreso Nacional de Filosofia: El marxismo de José Carlos Mariátegui (39-46). Lima: Universidad de Lima y Empresa Editora Minerva S.A.

Rouillón, G. (1963). Bio-bibliografía de José Carlos Mariátegui. Lima: Universidad Nacional Mayor de San Marcos.

Salazar Bondy, A. (1965). Historia de las ideas en el Perú contemporáneo. El proceso del pensamiento filosófico, 2 tomos. Lima: Francisco Moncloa Editores S.A.

Salazar Bondy, A. (2015). Repensar a Augusto Salazar Bondy: homenaje a los 90 años de su nacimiento. Editado por Joel Rojas Huaynates. Lima: Fondo Editorial de la Universidad Nacional Mayor de San Marcos.

Schutte, O. (1992). Nietzsche, Mariátegui y el socialismo: ¿un caso de "marxismo nietzscheano" en el Perú? Anuario mariateguiano, 4(4), 85-92.

Silvers, M. (1981). La formación de un revolucionario. En Podestá, B. (ed.), Mariátegui en Italia (19-78). Lima: Empresa Editora Minerva S. A. 
Sobrevilla, D. (2012). El marismo de Mariátegui y su aplicación a los 7 ensayos. Lima: Fondo Editorial de la Universidad de Lima.

Sorel, G. (2005). Reflexiones sobre la violencia. Madrid: Alianza Editorial.

Sorel, G. (2014). Descomposición del marxismo. Buenos Aires: Ediciones Godot.

Unamuno, M. de. (2007). La agonía del cristianismo. Madrid: Alianza Editorial.

Vanden, H. (1975). Mariátegui. Influencias en su formación ideológica. Lima: Empresa Editora Minerva S.A. 